\begin{tabular}{c} 
Volume and Issues Obtainable at Center for Sustainability Research and Consultancy \\
Journal of Accounting and Finance in Emerging Economies \\
ISSN: 2518-0318 ISSN (E) 2518-8488 \\
Volume 6: Issue 2 June 2020 \\
CSRᄃ \\
Journal homepage: $\underline{\text { www.publishing.globalcsrc.org/jafee }}$ \\
\hline
\end{tabular}

\title{
How Consumer Confidence, Corruption and Credit Rating Effect the Exchange Rate: Emerging Market Perspective
}

\author{
${ }^{1}$ Muhammad Asif Khan, ${ }^{2}$ Ghulam Mujtaba Chaudhary, ${ }^{3}$ Khalid Latif \\ ${ }^{1}$ Department of Commerce, University of Kotli Azad Jammu and Kashmir. \\ khanasif82@hotmail.com \\ ${ }^{2}$ Department of Business Administration, University of Kotli Azad Jammu and Kashmir. \\ ghulam.mujtaba@uokajk.edu.pk \\ ${ }^{3}$ College of Commerce, Government College University Faisalabad. \\ khalidlatif@gcuf.edu.pk
}

\begin{tabular}{l} 
ARTICLE DETAILS \\
History \\
Revised format: May 2020 \\
Available Online: June \\
2020 \\
Keywords \\
Co-integration, Exchange \\
Rate, Corruption Index, \\
Consumer Confidence, \\
Credit Rating \\
\hline
\end{tabular}

JEL Classification

F31, D73, G24, P24

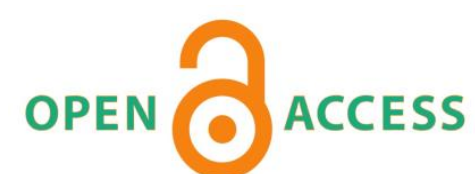

\begin{abstract}
The paper empirically examines whether international rating influences the rate of exchange of an economy in the long run? The paper employs Autoregressive Distributed Lag (ARDL) Bounds testing methodology on the exchange rate of China and contemporary international rating, using time series data from 1996Q1 to 2016Q4. The empirical analysis confirms the presence of a co-integration relationship between country rating and the exchange rate. To be more specific; corruption index, credit rating, and inflation are significantly and negatively cointegrated with the exchange rate of China. Conversely, consumer confidence is uncorrelated with the exchange rate over the long run. The results add to the exchange rate determinants literature by including country-rating indicators in the analysis. This research is novel in the application of robust ARDL and bounds testing to examine the long and short-run association of country rating of China with its exchange rate, after controlling for inflation.
\end{abstract}

(C) 2020 Center for Sustainability Research and Consultancy Pakistan under a Creative Commons Attribution-NonCommercial-ShareAlike 4.0

Corresponding author's email address: ghulam.mujtaba@uokajk.edu.pk

Recommended citation: Khan, M. A., Chaudhary, G.M., Latif, K. (2020). How Consumer Confidence, Corruption and Credit Rating Effect the Exchange Rate: Emerging Market Perspective. Journal of Accounting and Finance in Emerging Economies, 6 (2), 367-379.

\section{Introduction}

This paper empirically examines whether the exchange rate (XR) of China is influenced by its international rating, after controlling for inflation. XR postulates the health of an economy and effectiveness of macro and microeconomic policy if the currency of a country appreciates or at least remains stable over the long run. Volatility in exchange rate directly affects the balance of trade, therefore, stakeholders, such as practitioners, bankers, investors, and economists should anticipate the exchange rate particularly in terms of volatility and design policies accordingly because current account deficit coincide in those countries, where domestic currency is relatively volatile it results in pass-through effects on other adjacent factors (Grube \& Samanta, 2003; Gupta \& Kashyap, 2016). Foreign trade is another critical area in which China is most focused and USD / CNY is one of the significant determinants of Chinese exports due to its greater use (Hua \& Junjun, 2016). The empirical result of this study demonstrates that appreciation in Chinses currency against USD brings a negative change in Chinese exports. 
In the present global and technological era, the countries are not solely weighted subject to the rising volume of GDP and its growth rate, in fact, several other indicators have become a considerable prominent debate for investors and policymakers. Consumer confidence index (CCI), Corruption index (CI) and Credit ratings (CR) are among these indicators that source the economic and social standing of a country in a global environment. Potential capital inflows and inward foreign investments are heavily linked with an international rating nowadays. CCI assesses the overall confidence, power of spending and financial position of consumers. CCI is a useful measure of consumer aptitude; it has a causal relationship with economic growth, rising consumer confidence positively influences the growth and negative does otherwise (Sergeant, Lugay, \& Dookie, 2011; Tuba, Ismail, \& Ilkeryasin, 2016). Theoretically, improving consumer confidence decreases the demand for foreign currency, and the value of the domestic currency will increase. This connection holds true when the political and economic condition of a country is stable, and outsiders can use CCI for useful economic forecast and business planning in that particular country (Sakir \& Gunes, 2010).

CI reflects the collective mindset and course of action of public representatives and government officers, how they are using delegated power and financial resources. High CI contributes positively towards economic growth (Aljazaerli, Sirop, \& Mouselli, 2016) while low CI badly hamper the economic growth (Bolgorian, 2011). CR are the weights given by rating bodies. These weights portray the creditworthiness of a country and exposure of default when the national debt bubble magnifies to an unfavorable danger level. Role of rating agencies, ineffective rating announcements, and sharp response to policy amendments by a country counters the issue of information asymmetry to insiders and outsiders (Korkeamaki, Poyry, \& Suo, 2014). Improving rating builds the confidence of international investors as well as the confidence of residents, which poses a social impact on investment behaviors (Lee, Sapriza, \& $\mathrm{Wu}, 2016)$.

This study adds value to the XR literature in several ways. As far as we know, this is the first study to examine the short and long-term dynamics of XR using international rating indicators and to take into account the rate of adjustment to correct previous period disequilibrium in XR. Secondly, this work uses the robust ARDL bounds testing approach to co-integration, which has overwhelming functions compared to least-squares regression in mixed-order cases (Pesaran, Shin, \& Smith, 2001) and it is preferred to other co-integration methods (Engle \& Granger, 1987; Johansen \& Juselius, 1990). Moreover, this produces the best results in a situation where the sample size is small (Haug, 2002, Pesaran \& Shin, 1998). Third, the earlier literature documents that there is an indirect link between inflation and the XR that goes through import prices. This study provides indications of a direct, short and long-term relationship between inflation and XR. Finally, important international rating indicators are taken into account, such as CCI, CI and CR. Therefore, it expands relevant literature and opens the debate for future research.

\section{Review of Related Literature}

\subsection{Index of Consumer Confidence and Exchange Rate}

According to Matsusaka and Sbordone (1995), consumer confidence accounts for around 13-26\% of innovation variance in economic activity. Tsai, Liu, Liao, and Chang (2015) consider CCI among a set of a convenience factors to forecast foreign exchange rates using the GARCH model. Tsai et al. (2015) claimed that including CCI as one of the considered factors for foreign exchange rate forecasting with $\mathrm{GARCH}$ model improves foreign exchange rate forecasting accuracy than only with conventional variables. CCI is a useful measure of consumer aptitude; it has a causal relationship with economic growth, growing consumer confidence positively influences the growth and vice versa (Sergeant et al., 2011; Tuba et al., 2016).

It is believed that increased confidence brings prosperity by influencing economic variables positively, Sakir and Gunes (2010) found ARDL Bounds value lower than lower bound, indicating no long-run association; however, CCI has a short-run positive causal effect on the real exchange rate. Celik, Aslanoglu, and Uzun (2010) test the cointegration among CCI and financial market variables such as interest rate, exchange rate and stock indices. Empirical result validates the long-run equilibrium relationship among underlying variables. Based on literature, it is hypothesized that:

$\mathrm{H}_{1}$ : Increasing CCI results in an upsurge in the exchange rate. 


\subsection{Corruption Index and Exchange Rate}

According to Transparency International, "the corruption perception index (CI) ranks countries and territories based on how corrupt their public sector is perceived to be". Likewise, Jain (2001) tags corruption as "an act in which the public office uses its power to gain personal benefits in a contravening manner that violates the rule of law." According to Aljazaerli et al. (2016), there is a widespread debate on corruption and its economic consequences. It was reported that high CI positively drives the economic development. Bolgorian (2011) and Mo (2001) documented that high corruption hampers economic growth. Rodrik (2008), elucidates that economic growth has a strong linkage with the real exchange rate of that country. Ghura (1998), clarifies that corruption and changes in the real exchange rate are interconnected. Erhieyovwe and Onokero (2013 recommended that immediate actions against corruption should vigorously be persuaded to remold the negative image of the economy. To probe this issue, it is hypothesized:

$\mathrm{H}_{2}$ : Low CI increases the exchange rate.

\subsection{Credit Rating and Exchange Rate}

Financial firms use credit ratings as an essential tool for risk management technology, and level of these ratings varies over time with the change in credit risk (Puneet, Dharmaraja \& Viswanathan, 2017). Credit rating agencies play an important role in the financial markets by helping to reduce the information asymmetry between lenders, investors, and issuers about the creditworthiness of companies. The increasing globalization of the financial markets and, in particular, the emergence of Basel- $\mathrm{II}^{1}$ have broadened the role of rating agencies. Markets tend to stay calm and overreact with the sticky rating as they change (Li et al., 2019). This overreaction may have exacerbated financial crises in the past and led to financial instability (Elkhoury, 2009, Huang \& Shen, 2015, Lee et al., 2016). Similarly, Lee et al. (2016) confirm that changes in country ratings have a significant impact on liquidity; the impact is greater for downgrades than for upgrades.

CR not only reduces the information asymmetry, but also help to determine the fair prices in significant economic transactions (Jory, Ngo, \& Wang, 2016). It is evident that CR produces best possible outcome when rating agency immediately responds to policy changes announcements by a country, the slow response to such policy amendments or new policies seems likely to be a misfit (Fedderke, 2015). For empirical examination, the study hypothesized that: $\mathrm{H}_{3}$ : Improving $\mathrm{CR}$ contributes positively to the exchange rate.

\subsection{Inflation and Exchange Rate}

There is considerable research on linkage among inflation, exchange rate, and monetary and trade policies. According to Taylor (2001), policymakers need to consider a floating exchange rate, inflation, and monetary policy rules to establish a useful policy framework in an open economy. The empirical results of Bleaney and Fielding (2002), suggest inflation constitutes a significant cost concerning floating exchange rate adoption in developing countries. Kamin (1996) shows that the effects of inertial inflation are temporary in estimating real exchange rates, only lasts about a year after stabilization. Aliyu (2009) notes that the appreciation of the exchange rate increases import volumes, reduces export volumes. Adeniran, Yusuf and Adeyemi (2014) illustrate the positive effect of the exchange rate on economic growth.

The comparative analysis of 2008 financial crisis with some earlier periods shows that the XR accounts for a significant portion of global pre-crisis inflationary pressures. The spillover effects diffused by the exchange rate were the main reason for a noticeable deterioration in Swiss inflation since the crisis (Jordan, 2016). The inflation target reduces fluctuations in real XR and plays an important role in providing favourable evidence for long-term purchasing par parity (Kim, 2014). Another study on the role of inflation regimes in explaining the extent of the exchange rate transition to import prices shows that the group of countries with higher inflation rates has a higher level of foreign exchange import prices (Ben \& Louhichi, 2016).

Inflation and exchange rate are fundamental pillars considered in monetary and trade policies. Previous researches focused on the role of inflation in explaining exchange rate pass-through import prices indirectly, yet the direct causality needs to be explored, for which it is hypothesized:

\footnotetext{
${ }^{1}$ Basel-II has incorporated the rating of credit rating agencies among rules to assign weights for credit risk.
} 
$\mathrm{H}_{4}$ : Inflation has a causal effect on the exchange rate.

\section{Methodology}

\subsection{Data and Variables}

This study is led by secondary time series data over the period of 1996Q1 to 2016Q4 captured from various sources such as World Bank database for exchange rate, Trading Economics (TE) for CCI, Transparency International for CI and Moody's official web portal for CR grades, which are assigned score with reference to TE schedule ${ }^{2}$ A detailed description of all underlying variables and the measurement is provided in Appendix 1.

\subsection{Unit-Root Analysis}

The study applies Augmented Dickey-Fuller (ADF) and Phillip-Perron (PP) tests (Dickey \& Fuller, 1979, 1981) for analyzing stationarity problem using equation (1). Both these tests (ADF and PP) are very famous among academic scholars, see for example Chakraborty (2016), Gejalakshmi and Azhagaiah (2015), Sherry (2016), Jian Li, Xu, Xu, Tang, and Yu (2017), Mansourfar, Didar, and Jodatnia (2017), and Moussa, Ouda, and Delhoumi (2017).

$$
\Delta Y_{t}=\gamma_{0}+\rho_{1} Y_{t-1}+\sum_{j=1}^{p} d_{j} \Delta Y_{t-j}+\varepsilon_{t}
$$

Where, $\Delta Y_{t}$ is difference operator in variable $\mathrm{Y}$ over time t. Yt-1 is the value of variable $\mathrm{Y}$ at time t-1, $\gamma_{0}$ and $\rho_{1}$ are the coefficients of estimations, and $\varepsilon$ is error-term, $\mathrm{p}$ denotes optimal lag length. Table 1 assimilates the unit-root test results with respect to CCI and XR both are stationary at the level I(0), while CI, CR and CPI, are stationary at first difference I(1). These mixed results of stationary suggest that the ARDL Bounds testing approach of cointegration is suitable for analysis.

Table 1: Augmented Dickey-Fuller Unit Root Test Results

\begin{tabular}{|c|c|c|c|c|}
\hline \multirow[b]{2}{*}{ Variable } & \multirow[b]{2}{*}{ Acronym } & \multicolumn{2}{|c|}{ ADF Value } & \multirow{2}{*}{$\begin{array}{c}\text { ADF Critical } \\
\text { Value } \\
\text { (at 5\%) }\end{array}$} \\
\hline & & At Level & At $1^{\text {st }}$ Diff. & \\
\hline Consumer Confidence Index & CCI & $-4.063 * *$ & $-10.107 * *$ & -3.457 \\
\hline Corruption Index & $\mathrm{CI}$ & -2.445 & $-9.750 * *$ & -3.457 \\
\hline Credit Rating & $\mathrm{CR}$ & -1.421 & $-9.929 * *$ & -3.458 \\
\hline Consumer Price Index & CPI & -2.313 & $-6.079 * *$ & -3.459 \\
\hline Exchange Rage & $\mathrm{XR}$ & $-5.937 * *$ & $-6.811 * *$ & -3.458 \\
\hline Error Correction Term ${ }^{* * *}$ & ECT & $-10.359 * *$ & $-11.006^{* *}$ & -3.458 \\
\hline
\end{tabular}

$(*)$ and $(* *)$ indicates significant at $5 \%$ and $1 \%$ level respectively

This study further uses Akaike Information Criteria (AIC) and Schwarz information criterion (SIC) to choose optimal lag. The results suggest lag 1 as appropriate for the current model.

\subsection{ARDL Bounds Test of Cointegration}

Cointegration is linear stationery and long-run equilibrium relationship among two or more non-stationary time series variables (Engle \& Granger, 1987). The study applies the ARDL Bounds Test approach of cointegration of Pesaran et al. (2001), to capture the long-run equilibrium relationship among international country rating and China exchange rate. The rationale behind the ARDL approach is the flexibility in integration order for variables under focus [I(1), $\mathrm{I}(0)$ and $\mathrm{I}(1)-\mathrm{I}(0)]$. Our sample size is small, and ADF and PP tests depict the mixed integration order concerning variables. The ARDL approach yields the best estimation, principally in case of small sample size and mixed integration order (Haug, 2002; Pesaran \& Shin, 1998) that is why this approach is preferred over other cointegration approaches (Engle \& Granger, 1987; Johansen \& Juselius, 1990). Finally, we employ ECM to affirm the long-run relationship, identified via the ARDL Bounds Test. The choice of ARDL gains support of previous studies those

\footnotetext{
2 details may be seen at https://tradingeconomics.com/country-list/rating
} 
address the similar phenomena, see, for example (Khan, Ilyas, \& Hashmi, 2018; Khan, Khan, Abdulahi, Liaqat, \& Shah, 2019; Rehman, Khan, Khan, Pervaiz, \& Liaqat, 2020). The hypothetical model that transports the relationship between China international rating and its exchange rate can be expressed as;

$$
X R_{(C N Y \sim U S D)}=\mathrm{f}(\mathrm{CCI}, \mathrm{CI}, \mathrm{CR}, \mathrm{CPI})
$$

Here $\mathrm{XR}=$ Exchange rate of Chinese Yuan concerning UD dollar, $\mathrm{CCI}=$ Consumer confidence index, $\mathrm{CI}=$ Corruption perception index, $\mathrm{CR}=$ Credit rating (Moody's in our case), and CPI $=$ Consumer price index. The econometrical expression of equation (2) is as follows;

$$
X R_{(C N Y \sim U S D) t}=\alpha_{0}+\beta_{1} C C I_{t}+\beta_{2} C I_{t}+\beta_{3} C R_{t}+\beta_{4} C P I_{t}+\mu_{t}
$$

ARDL regression equation for econometrics model (eq. 3) can be written as;

$$
\begin{gathered}
X R_{(C N Y \sim U S D) t}=\omega_{0}+\beta_{1} C C I_{t}+\beta_{2} C I_{t}+\beta_{3} C R_{t}+\beta_{4} C P I_{t} \\
+\sum_{t-1}^{p} \lambda_{1} \triangle X R_{t-1}+\sum_{t-1}^{p} \partial_{2} \Delta C C_{t-1}+\sum_{t-1}^{p} \partial_{2} \Delta C I_{t-1} \\
+\sum_{t-1}^{p} \partial_{3} \triangle C R_{t-1}+\sum_{t-1}^{p} \partial_{4} \triangle C P I_{t-1}+\mu_{t}
\end{gathered}
$$

Here $\triangle$ is the difference operator and $p$ is the optimal number of lags.

\subsection{Short and Long-Run Equilibrium Relationship}

After confirmation of long-run association, error correction model (ECM) is applied to estimate the short-run relationship among underlying variables. The sign of ECT must be negative and statistically significant, with a coefficient $(\eta)$ ranging between zero and one, represents the speed of adjustment towards long-run equilibrium after a short-term shock that confirms the stability of the system. We estimate the following equation (5) for this purpose;

$$
\begin{aligned}
\Delta X R_{t}=\omega_{0}+ & \xi_{1} C C I_{t}+\xi_{2} C I_{t}+\xi_{3} C R_{t}+\xi_{4} C P I_{t} \\
& +\xi_{5} \sum_{i=1}^{p} \Delta C C I_{t-1}+\xi_{6} \sum_{i=1}^{p} \Delta C I_{t-1}+\xi_{7} \sum_{i=1}^{p} \Delta C R_{t-1} \\
& +\xi_{8} \sum_{i=1}^{p} \triangle C P I_{t-1}+\eta E C T_{t-1}+\mu_{t}
\end{aligned}
$$

Where "ECT $\mathrm{t}-1$ " symbolizes the error correction term with $\eta$ percent speed of adjustment, $\xi_{1}$ to $\xi_{4}$ are respective longrun coefficient while $\xi_{5}$ to $\xi_{8}$ are thought to be as short-run coefficients respectively.

\subsection{Multicollinearity Detection}

To handle the multicollinearity issue, the study employs VIF test with the help of facing equation;

$$
V I F=\frac{1}{1-R^{2}}
$$

Equation (6) captures $\mathrm{R}^{2}$ through auxiliary regression with the benchmark, if VIR value outstrips five (VIF>5), this is indications of the strong interrelationship between the focus list of independent variables, and situation asks for a suitable alternative or give-up the conflicting variable if a near substitute is not approachable. 


\section{Empirical Results}

In this section, empirical results of ARDL Bounds test, long and short-run relationship, diagnostic tests, error correction model and stability tests are discussed. Null hypothesis is that there is no cointegration among variables.

Table 2: ARDL Bounds Test

\begin{tabular}{cccc}
\hline \multicolumn{2}{c}{ Bounds Test Values } & \multicolumn{2}{c}{ Critical Values Bounds } \\
\hline Test Statistic & Value & I0 Bound & I1 Bound \\
F-statistics & $4.701^{*}$ & 2.86 & 4.01 \\
\hline
\end{tabular}

The critical value is selected at a 5\% significance level, while $(*)$ indicates the rejection of the null hypothesis

ARDL Bounds Test result is presented in Table 2, bounds test value (4.701) is compared with lower and upper bound value, which is higher than upper bound (4.01), indicates long-run co-movement of the country ratings with its XR during the study period 1996Q1 to 2016Q4. We reject the null hypothesis of no cointegration and accept the alternative hypothesis, which holds a long-run equilibrium relationship between the XR and set of regressors under study. The results of the ARDL indicating long-run relationship among variables are in Table 3.

Table 3: ARDL Cointegrating Long Run Form

\begin{tabular}{rcccc}
\hline Variable & Coefficient & Std. Error & t-Statistic & Prob. \\
\hline CCI & 0.009 & 0.019 & 0.508 & 0.615 \\
CI & -0.082 & 0.022 & -3.649 & 0.001 \\
CR & -0.103 & 0.015 & -6.747 & 0.000 \\
CPI & 0.317 & 0.038 & 8.165 & 0.000 \\
C & 0.246 & 0.058 & 4.190 & 0.002 \\
\hline Adjusted R-squared & 0.913 & F-statistics & & 200.507 \\
Durbin-Watson stat & 2.028 & Prob(F-statistcs) & & 0.000 \\
\hline
\end{tabular}

Consistent with ARDL Bounds test results, the negative sign of cointegration coefficients and significant p-value suggest a long-run association between XR and international country rating indicators. CCI although has a positive sign, yet p-value indicates the insignificant long-run impact on XR of China. The rest of the international country rating indicators such as CI and CR have a negative and significant long-run association with China's XR. Relatively high corruption causes the lower CI, which consequently depreciates the currency (Erhieyovwe \& Onokero, 2013). CR lessens the information asymmetry and helps to determine fair prices in major economic transactions (Jory et al., 2016).

CPI causes the depreciation of Chinese yuan over the long run. This is consistent with past studies, such as Yanamandra (2015), which shows that inflationary pressure results in depreciation of XR. Similarly, Ben and Louhichi's (2016) argument of a high inflation rate comes up with high XR passes through import prices. The second part of Table 3 illustrates the predictability of the model with adjusted R-square appears very good with prediction power of $92 \%$. Significant F-statistics value entails the suitability of the model for estimation. Durbin-Watson statistics implies no autocorrelation problem in the model.

To confirm the cointegration among variables identified via the ARDL Bounds test, ECM is applied to estimate shortrun dynamics and speed of adjustment towards long-run equilibrium. ECM results are reported in table 4 and sign of the coefficient of ECT is negative and significant, that gestures long-run equilibrium relationship and indicates that system corrects previous period disequilibrium at a speed of $12.89 \%$ quarterly and convergence towards long-run equilibrium. Results prove the metaphor future is relevant to past and XR prediction is concurrent to its past position. $\mathrm{CCI}$ has a short-term negative impact on XR. The coefficient of $\mathrm{CI}$ is negative but insignificant, shows Chinese XR is least sensitive to increasing corruption over the short run. 
Table 4: Error Correction Model

\begin{tabular}{lrrrr}
\hline$\Delta(\mathrm{XR})$ & 0.906 & 0.179 & 5.060 & 0.000 \\
$\Delta(\mathrm{CCI})$ & -0.022 & 0.009 & -2.392 & 0.018 \\
$\Delta(\mathrm{CI})$ & -0.021 & 0.024 & -0.908 & 0.366 \\
$\Delta(\mathrm{CPI})$ & 0.232 & 0.096 & 2.399 & 0.023 \\
$\Delta(\mathrm{CR})$ & -0.096 & 0.021 & -4.567 & 0.000 \\
$\mathrm{ECT}_{\mathrm{t}-1}$ & -0.128 & 0.022 & -5.859 & 0.000 \\
$\mathrm{C}$ & 0.091 & 0.028 & 3.261 & 0.002 \\
\hline
\end{tabular}

According to Bolgorian (2011) and Mo (2001), high corruption harmfully affects economic growth. Therefore a negative sign of coefficient clarifies this sentiment. CR negatively and significantly influences the Yuan XR that is possibly due to the dynamic role of rating agencies and immediate reaction towards unfavorable information about the country's sovereign position. Existing literature reveals that the market remains unruffled with the sticky rating and overplay in response to change and such reaction has intensified financial crises in the past (Elkhoury, 2009; Huang \& Shen, 2015; Lee et al., 2016). In the long run, CPI is a significant determinant of economic growth and monetary policy framework. Policymakers should consider the interplay of XR and inflation while devising monetary policy (Taylor, 2001).

Table 5: Diagnostic and Stability Analysis of Model

\begin{tabular}{lcc}
\hline Test & F-statistic & Prob. \\
\hline Jarque-Bera & 5.573 & 0.061 \\
Breusch-Pagan-Godfrey & 1.175 & 0.313 \\
Breusch-Godfrey LM Test & 0.713 & 0.851 \\
Ramsey RESET & 1.541 & 0.217 \\
CUSUM Test & Stable &
\end{tabular}

CUSUM of Squares Test

Stable

Jarque-Bera is applied for normality conditions; the Breusch-Pagan-Godfrey test for checking

Heteroskedasticity and Breusch-Godfrey LM Test for serial correlation.

Diagnostic and stability analysis in table 5 affirms that the model used for estimation fulfills the preliminary tests desired for a good model. Jarque-Bera test provides the normality assumption with a p-value higher than the benchmark, which means data are normally distributed. F-statistics and p-value corresponding to the Breusch-PaganGodfrey test and Breusch-Godfrey LM test signify that the research model is free from serial correlation and heteroskedasticity problems. The results of the Ramsey RESET test holds the model is stable. CUSUM test shows that the underlying parameters are stable. Similarly, CUSUM of Squares test authenticates the systematic movement of parameters during the study period (see Appendix 2a and 2b).

Variance inflation factor measures the multicollinearity among a set of regressors. Table 6 communicates the results of VIF for all independent variables and demonstrates the non-existence of collinearity problem, as VIF corresponding to CCI, CI, CPI and CR are less than five.

Table 6: Variance Inflation Factors

\begin{tabular}{ccc}
\hline Variable & Variance & VIF \\
\hline CCI & 0.000 & $2.942^{*}$ \\
CI & 0.000 & $4.698^{*}$ \\
CPI & 0.000 & $3.130^{*}$ \\
CR & 0.000 & $3.384^{*}$ \\
\hline
\end{tabular}

$(*)$ indicates if $\mathrm{VIF}<5$ 


\section{Conclusion, and recommendations}

We empirically examined whether the exchange rate of a China (CYN-USD) is influenced by China's international ratings such as CCI, CI, and CR after controlling for inflation. Stationarity analysis is conducted through ADF and PP tests (Dickey \& Fuller, 1979, 1981) and it is found that CCI and XR both are stationary at level I(0), although CI, CR, and CPI are stationary at first difference I(1). This mixed integration order suggests that the ARDL Bounds testing approach of cointegration of Pesaran et al. (2001) is suitable for analysis and ECM to affirm long-run association among underlying variables and XR of China. We also applied diagnostic tests like Jarque-Bera for normality conditions; Breusch-Pagan-Godfrey test for checking Heteroskedasticity and Breusch-Godfrey LM Test for serial correlation. Diagnostic testing shows that data is normally distributed and the model is free from autocorrelation and heteroskedasticity. Parameters stability has been assessed through CUSUM and CUSUM of Squares test, and respective results assure the stability and their systematic movement of the parameters over the span of the study period. The results of Ramsey RESET test hold that the model used for estimation is stable. To handle the multicollinearity, issue the study employs VIF, articulates that all independent variables do not have collinearity problems.

The empirical result of the ARDL Bounds test demonstrates that cointegration exists between China's internal rating and its XR after controlling for inflation. Individually, CI and CR are significantly and negatively cointegrated with Yuan XR measured regarding USD. Conversely, CCI is uncorrelated with the exchange rate over the long run although it has a positive sign that is consistent with theory. Relatively high corruption causes the lower CI, which consequently depreciates the currency (Erhieyovwe \& Onokero, 2013). The CR lessens the information asymmetry and helps to determine the fair prices in major economic transactions (Jory et al., 2016). CR yields the optimal outcomes when the role of such agencies is efficient in response to policy changes (Fedderke, 2015). CPI is the root cause of the depreciation of Chinese yuan over the long run, consistent with the findings of Yanamandra (2015) that inflationary pressure results in the depreciation of XR that ultimately influences the price of imports both in short and long-run. The negative and statistically significant coefficient for ECM guarantees a long-term equilibrium relationship between underlying variables and indicates that the system corrects the previous period disequilibrium with a quarterly rate of $12.89 \%$ and a long-term equilibrium convergence.

The study offers policymakers to forecast stock market sentiments carefully. According to Charles, Nicholas, and Kofi (2011), there is a short-run and long-run relationship between stock prices and exchange rate, and exchange rate depreciation results in stock price downward movement. Jayashankar and Rath (2017)) strengthened this phenomenon by arguing that foreign exchange market, stock market, and money market are cointegrated and shocks in one can spillover to others in the meantime. Chinese stock market has encountered a severe problem in the last few years. Therefore, an investor should take care of the RMB exchange rate regarding dominant global currencies.

The paper focuses only on the exchange rate of CNY-USD; this may limit the generalizability of results for XR with other nations. Nevertheless, the results add to the XR determinants literature by including country-rating indicators in the analysis. Prior literature documented that there is an indirect relationship between inflation and XR passes through import prices. This is the first paper that uses robust ARDL and bounds testing to examine the long-run equilibrium and short-run dynamic association of country international rating with XR, after controlling for inflation, therefore extends the literature in this vital area. Our model generates a rich set of implications on how CCI, CI, CR, and XR co-move. Our estimation validates the theoretical prediction, yet a lot to be explored since XR has a wide range of predictors such as trade policies, trade barriers, and monetary policy, economic, financial and political risk. A reasonable extension of this study may produce impressive results; if the pass-through effect of these predictors is measured on foreign trade of China.

\section{References}

Adeniran, J., Yusuf, S., \& Adeyemi, O. A. (2014). The impact of exchange rate fluctuation on the Nigerian economic growth: An empirical investigation. International Journal of Academic Research in Business and Social Sciences, 4(8), 224. 
Aliyu, S. U. R. (2009). Impact of oil price shock and exchange rate volatility on economic growth in Nigeria: An empirical investigation. MPRA Paper No. 16319, available online at http://mpra.ub.uni-muenchen.de/16319/.

Aljazaerli, M. A., Sirop, R., \& Mouselli, S. (2016). Corruption and stock market development: New evidence from GCC countries. Verslas: teorija ir praktika, 17(2), 117-127.

Ben, C. N., \& Louhichi, W. (2016). Revisiting the role of inflation environment in exchange rate pass-through: A panel threshold approach. Economic Modelling, 52, Part A, 233-238. doi:

Bleaney, M., \& Fielding, D. (2002). Exchange rate regimes, inflation, and output volatility in developing countries. Journal of Development Economics, 68(1), 233-245.

Bolgorian, M. (2011). Corruption and stock market development: A quantitative approach. Physica A: Statistical Mechanics and its Applications, 390(23-24), 4514-4521.

Celik, S., Aslanoglu, E., \& Uzun, S. (2010). The relationship between consumer confidence and financial market: Variables in Turkey during the global crisis. Topics in Middle Eastern and African Economies, 12, 1-17.

Chakraborty, A. (2016). Stock market inter-linkages: Evidence from India and other developed markets. IIMS Journal of Management Science, 7(1), 134-144.

Charles, K. D., Adjasi, Nicholas, B., Biekpe, \& Kofi, A., Osei. (2011). Stock prices and exchange rate dynamics in selected African countries: a bivariate analysis. African Journal of Economic and Management Studies, 2(2), 143-164.

Dickey, D. A., \& Fuller, W. A. (1979). Distribution of the estimators for autoregressive time series with a unit root. Journal of the American Statistical Association, 74(366a), 427-431.

Dickey, D. A., \& Fuller, W. A. (1981). Likelihood ratio statistics for autoregressive time series with a unit root. Econometrica: Journal of the Econometric Society, 1057-1072.

Elkhoury, M. (2009). Credit rating agencies and their potential impact on developing countries. UNCTD Compendium on Debt Sustainability, 165-180.

Engle, R. F., \& Granger, C. W. (1987). Co-integration and error correction: representation, estimation, and testing. Econometrica: Journal of the Econometric Society, 251-276.

Erhieyovwe, E. K., \& Onokero, I. I. (2013). Corruption, foreign direct investment and its impact on exchange rate of the Nigerian economy. Mediterranean Journal of Social Sciences, 4(3), 345.

Fedderke, J. (2015). Promotion and relegation between country risk classes as maintained by country risk rating agencies. Procedia Economics and Finance, 29, 158-182.

Gejalakshmi, S., \& Azhagaiah, R. (2015). Impact of financial meltdown on the relationship between dividend policy and shareholders' wealth. Management, University of Primorska, Faculty of Management Koper, 10 (4), 355377.

Ghura, D. (1998). Tax revenue in Sub-Saharan Africa: effects of economic policies and corruption. IMF Working Paper, WP/98/135, SSRN-id882694.

Grube, B. T., \& Samanta, S. K. (2003). Effects of exchange rate uncertainty on Mexican foreign trade. Multinational Business Review, 11(2), 3-16.

Gupta, S., \& Kashyap, S. (2016). Modeling volatility and forecasting of the exchange rate of British pound sterling and Indian rupee. Journal of Modelling in Management, 11(2), 389-404.

Haug, A. A. (2002). Temporal aggregation and the power of cointegration tests: a Monte Carlo study. Oxford Bulletin of Economics and Statistics, 64(4), 399-412.

Hua, W., \& Junjun, Z. (2016). The influence of USD/CNY foreign exchange rate, RMB NEER and spatial effects on China's foreign trade. China Finance Review International, 6(3), 304-318.

Huang, Y.-L., \& Shen, C.-H. (2015). Cross-country variations in capital structure adjustment-The role of credit ratings. International Review of Economics \& Finance, 39, 277-294.

Jain, A. K. (2001). Corruption: A review. Journal of Economic Surveys, 15(1), 71-121.

Jayashankar, M., \& Rath, B. N. (2017). The dynamic linkage between exchange rate, stock price and interest rate in India. Studies in Economics and Finance, 34(3), 383-406.

Johansen, S., \& Juselius, K. (1990). Maximum likelihood estimation and inference on cointegration with applications to the demand for money. Oxford Bulletin of Economics and Statistics, 52(2), 169-210.

Jordan, T. J. (2016). The impact of international spillovers on Swis s inflation and the exchange rate. Journal of International Money and Finance, 68, 262-265.

Jory, S. R., Ngo, T. N., \& Wang, D. (2016). Credit ratings and the premiums paid in mergers and acquisitions. Journal of Empirical Finance, 39, 93-104. 
Kamin, S. B. (1996). Real Exchange rates and Inflation in exchange-Rate based Stabilizations: an empirical examination. Journal of Developmen Economics, 64, 237-253.

Khan, M. A., Ilyas, R. M. A., \& Hashmi, S. H. (2018). Cointegration between institutional quality and stock market development. NUML International Journal of Business \& Management, 13(2), 90-103.

Khan, M. A., Khan, M. A., Abdulahi, M. E., Liaqat, I., \& Shah, S. S. H. (2019). Institutional quality and financial development: The United States perspective. Journal of Multinational Financial Management, 49, 67-80.

Kim, J. (2014). Inflation targeting and real exchange rates: A bias correction approach. Economics Letters, 125(2), 253-256.

Korkeamaki, T., Poyry, S., \& Suo, M. (2014). Credit ratings and information asymmetry on the Chinese syndicated loan market. China Economic Review, 31, 1-16.

Lee, K.-H., Sapriza, H., \& Wu, Y. (2016). Sovereign debt ratings and stock liquidity around the World. Journal of Banking \& Finance, 73, 99-112.

Li, C., Pervaiz, K., Asif Khan, M., Rehman, F. U., \& Oláh, J. (2019). On the asymmetries of sovereign credit rating announcements and financial market development in the European region. Sustainability, 11(6636), 1-14.

Li, J., Xu, Z., Xu, H., Tang, L., \& Yu, L. (2017). Forecasting oil price trends with sentiment of online news articles. Asia-Pacific Journal of Operational Research, 34(2), 1740019.

Mansourfar, G., Didar, H., \& Jodatnia, S. (2017). International portfolio diversification at industry level within SouthEast Asian stock markets. Iranian Journal of Management Studies, 10(1), 91-112.

Matsusaka, J. G., \& Sbordone, A. M. (1995). Consumer confidence and economic fluctuations. Economic Inquiry, 33(2), 296-318.

Mo, P. H. (2001). Corruption and economic growth. Journal of Comparative Economics, 29(1), 66-79.

Moussa, F., Ouda, O. B., \& Delhoumi, E. (2017). The use of open source internet to analysis and predict stock market trading volume. Research in International Business and Finance, 41, 399-411.

Pesaran, M. H., \& Shin, Y. (1998). An autoregressive distributed-lag modeling approach to cointegration analysis. Econometric Society Monographs, 31, 371-413.

Pesaran, M. H., Shin, Y., \& Smith, R. J. (2001). Bounds testing approaches to the analysis of level relationships. Journal of applied econometrics, 16(3), 289-326.

Puneet, P., Dharmaraja, S., \& Viswanathan, A. (2017). Markov regenerative credit rating model. The Journal of Risk Finance, 18(3), 311-325.

Rehman, F. U., Khan, M. A., Khan, M. A., Pervaiz, K., \& Liaqat, I. (2020). The causal, linear and nonlinear nexus between sectoral FDI and infrastructure in Pakistan: Using a new global infrastructure index. Research in International Business and Finance, 52, 101-129.

Rodrik, D. (2008). The real exchange rate and economic growth. Brookings Papers on Economic Activity, 2008(2), 365-412.

Sakir, G., \& Gunes, S. (2010). Consumer confidence, stock prices and exchange rates: The case Of Turkey. Applied Econometrics and International Development, 10(2), 103-114.

Sergeant, K., Lugay, B., \& Dookie, M. (2011). Consumer confidence and economic growth: case studies of Jamaica and Trinidad and Tobago. Economic Commission for Latin America and the Caribbean (ECLAC), LC/W.545, LC/L.352.

Sherry, A. (2016). Coincidental Indicators of Indian Business Cycles: A Time-Series Analysis. IIMS Journal of Management Science, 7(3), 316-339.

Taylor, J. B. (2001). The role of the exchange rate in monetary-policy rules. The American Economic Review, 91(2), 263-267.

Tsai, P., Wei, Liu, C., Han, Liao, L., Chao, \& Chang, J., Fang. (2015). Using consumer confidence index in the foreign exchange rate forecasting. Paper presented at the Intelligent Information Hiding and Multimedia Signal Processing (IIH-MSP), 2015 International Conference on.

Tuba, T., Isik, Ismail, S., \& Ilkeryasin, A. (2016). Consumer Confidence Index, the Relationship between Growth and Inflation. International Journal of Economics, Commerce and Management, 4(4), 295-306.

Yanamandra, V. (2015). Exchange rate changes and inflation in India: What is the extent of exchange rate passthrough to imports? Economic Analysis and Policy, 47, 57-68. 
Table 1: Measurement of Variables

\begin{tabular}{|c|c|c|c|c|}
\hline Indicator & Proxy & Measurement of proxy & Literature & $\begin{array}{c}\text { Data Bank } \\
\text { (agency) }\end{array}$ \\
\hline $\begin{array}{l}\text { Exchange } \\
\text { Rate }\end{array}$ & $\mathrm{XR}$ & $\begin{array}{l}\text { "China's exchange rate is the measure of the one unit of a Chinese } \\
\text { Yuan against the US dollar." }\end{array}$ & $\begin{array}{l}\text { Celik et al. } \\
\quad(2010) \\
\text { Yanamandra } \\
(2015)\end{array}$ & $\begin{array}{l}\text { World } \\
\text { Development } \\
\text { Indicators }\end{array}$ \\
\hline $\begin{array}{l}\text { Consumer } \\
\text { Confidence } \\
\text { Index }\end{array}$ & $\mathrm{CCI}$ & $\begin{array}{l}\text { In China, "the consumer confidence index (CCI) is based on a } \\
\text { survey of } 700 \text { individuals over } 15 \text { years old from } 20 \text { cities all over } \\
\text { the country. This composite index covers the consumer expectation } \\
\text { and consumer satisfaction index, thus measures the consumers' } \\
\text { degree of satisfaction about the current economic situation and } \\
\text { expectation on the future economic trend. The Index measures } \\
\text { consumer confidence on a scale of } 0 \text { to } 200 \text {, where } 200 \text { indicates } \\
\text { extreme optimism, } 0 \text { extreme pessimism, and } 100 \text { neutrality." }\end{array}$ & $\begin{array}{l}\text { Tsai et al. (2015) } \\
\text { Sakir and Gunes } \\
\text { (2010) } \\
\text { Celik et al. } \\
\text { (2010) }\end{array}$ & $\begin{array}{l}\text { Trading } \\
\text { Economics } \\
(\mathrm{TE})\end{array}$ \\
\hline $\begin{array}{l}\text { Corruption } \\
\text { Index }\end{array}$ & $\mathrm{CI}$ & $\begin{array}{l}\text { In China, "the Corruption Perceptions Index (CI) ranks countries } \\
\text { and territories based on how corrupt their public sector is perceived } \\
\text { to be. A country or territory's score indicates the perceived level of } \\
\text { public sector corruption on a scale of } 0 \text { (highly corrupt) to } 100 \\
\text { (very clean)." }\end{array}$ & $\begin{array}{l}\text { Erhieyovwe and } \\
\text { Onokero (2013) }\end{array}$ & $\begin{array}{l}\text { Transparency } \\
\text { International } \\
\text { and-TE }\end{array}$ \\
\hline $\begin{array}{l}\text { Credit } \\
\text { Rating }\end{array}$ & CR & $\begin{array}{l}\text { "The study uses Moody's Credit Ratings (CR), and numeric scores } \\
\text { are assigned using the schedule offered by Trading Economics } \\
\text { credit rating scores. The creditworthiness of a country between } 100 \\
\text { (riskless) and } 0 \text { (likely to default). Unlike the ratings provided by } \\
\text { the major credit agencies, this index is numerical because it is } \\
\text { easier to understand and more insightful for estimation and } \\
\text { comparison." }\end{array}$ & $\begin{array}{l}\text { (Li et al., 2019; } \\
\text { Fedderke, 2015) }\end{array}$ & $\begin{array}{l}\text { Moody's and } \\
\text { TE }\end{array}$ \\
\hline Inflation & CPI & $\begin{array}{l}\text { In China, "the Consumer Price Index or CPI measures changes in } \\
\text { the prices paid by consumers for a basket of goods and services, } \\
\text { that may be fixed or changed at specified intervals, such as yearly, } \\
\text { half-yearly and quarterly." }\end{array}$ & $\begin{array}{l}\text { Yanamandra } \\
\text { (2015) } \\
\text { Ben and } \\
\text { Louhichi (2016) } \\
\end{array}$ & $\begin{array}{l}\text { World } \\
\text { Development } \\
\text { Indicators }\end{array}$ \\
\hline
\end{tabular}



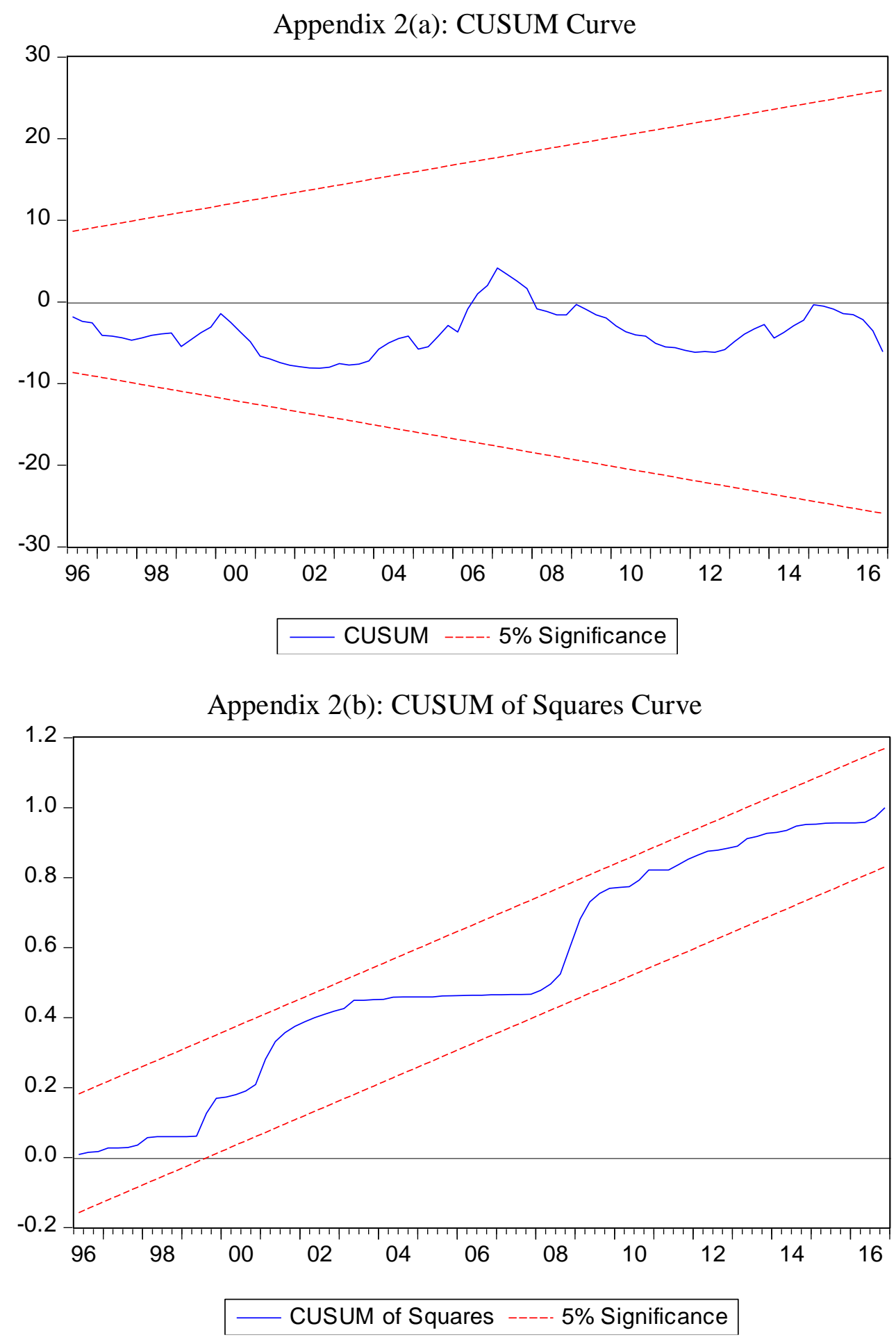